\title{
Influence of Sowing Window and Plant Density on Growth, Phenology, Yield and Quality of Nigella sativa L. in Coastal Humid Tropic
}

\author{
K. Giridhar ${ }^{1 *}$, G. Sathyanarayana Reddy ${ }^{2}$, S. Surya Kumari ${ }^{1}$, \\ A. Lalitha Kumari ${ }^{3}$ and A. Sivasankar ${ }^{4}$ \\ ${ }^{1}$ Dr. Y.S.R. Horticultural University, AICRP on Spices, Guntur, Andhra Pradesh, India \\ ${ }^{2}$ Sri Konda Lakshman Telangana State Horticultural University, Rajendranagar, \\ Hyderabad - 500030, India \\ ${ }^{3}$ Regional Research Unit (SSAC), Regional Agricultural Research Station, ANGRAU, \\ Lam, Guntur - 522034, India \\ ${ }^{4}$ Acharya N.G. Ranga Agricultural University, Rajendranagar, Hyderabad - 500030, India \\ *Corresponding author
}

\section{A B S T R A C T}

Nigella (Nigella sativa L.) has been widely acknowledged for its immense medicinal properties in different medicinal systems. Recognizing the importance of the crop as a potential component in crop diversification in Coastal Humid Tropic of India, a systematic study on the effect of date of sowing and plant densities on growth, yield and quality of nigella was under taken during winter growing season $(\mathrm{rabi})$. The different dates of sowing had significant influence on growth and yield of nigella. Delay in sowing caused reduction in growth, phenology, yield and quality. The optimum sowing time in Coastal Humid Tropic of India was found to be between $1^{\text {st }}$ fortnights of October to $1^{\text {st }}$ fortnight of November, sowing beyond this period had undesirable effects on the crop. Plant densities had significant effect on plant growth and quality of nigella. The individual growth parameters of the crop were lowest in the crop sown with 50 plants $\mathrm{m}^{-2}$. However, grain, fixed oil and essential oil yields were higher in the density of 50 plants $\mathrm{m}^{-2}$. Maximum seed yield $\left(\mathrm{kg} \mathrm{ha}^{-1}\right)$, stalk yield $\left(\mathrm{g} \mathrm{m}^{-2}\right)$, fixed oil yield $\left(\mathrm{kg} \mathrm{ha}^{-1}\right)$ and essential oil yield (L $\mathrm{ha}^{-1}$ ) were recorded in the first three dates of sowing (sowing window between $1^{\text {st }}$ fortnight of October to $1^{\text {st }}$ fortnight of November) at 50 plants $\mathrm{m}^{-2}$ density.

\section{Introduction}

Nigella (Nigella sativa L.) is a field crop that belongs to Ranunculaceae, the butter cup family. The seeds, which resemble onion seed, are used both as spice and medicine. The word nigella originated from the Latin word niger, which means blackish, referring to its seed colour. It is commonly referred as black-caraway, black-cumin, fennel-flower, nigella, nutmeg-flower and roman-coriander in English. It is known vernacularly by name habbatul barakah (Arabic for seed of blessing), shonaiz (Persian), kalonji (Urdu and Hindi) and krishnajirika (Sanskrit). The existence of numerous vernacular names indicated the wide use of nigella in more than 100 countries (Giridhar et al., 2015). Seeds of this plant are used both as spice and medicine since a very long time. The crop originated in 
the Mediterranean region and subsequently spread to Europe, Asia and Africa. The seeds are bitter in taste due to the presence of a seed protein, nigellin. The spice is highly regarded for its medicinal values in Greco Arab/Unani Tibb system of medicine, which originated from Hippocrates (Shrivastava et al., 2011). Nigella is known to have numerous medicinal properties and is widely used in unani, ayurveda, siddha and other ethnomedicine systems across the world. The medicinal value of the spice is immense and numerous workers appreciated its unique, varied and powerful pharmacological traits. Its pharmacological action such as anti-tumour, anti-diabetic, cardioprotective, gastro protective, antiasthmatic, nephroprotective, hepatoprotective, antiinflmmatory, immuno modulatory, neuroprotective, anticonvulsant, anxiolytic, antioxidant, antinociceptive, antioxytocic, contraceptive, abortifacient, antiimplantation, diuretic, antiurolithiatic, antispasmolytic, antibacterial, antifungal, anti-schistosomiasis and anthelmintic activities were immensely appreciated.

Although the global production and trade statistics of nigella are not available, it is reasonably estimated to be between 30000 metric tonne (MT) to $40000 \mathrm{MT}$. India alone produces 15000-20000 MT. The other important producers are Sri Lanka, Bangladesh, Afghanistan, Pakistan, Egypt, Iran, Iraq, Syria, Turkey and Ethiopia (Malhotra, 2004; Wallace, 2013). Giridhar et al., (2015) reported that India exported 20215 MT of nigella to Pakistan, Turkey, United States, Iran, UAE, Yemen, Tunisia, Germany, Sri Lanka and Indonesia during the year 2014. In India, nigella is generally grown in Northern parts during winter (rabi), where length of growing period is between 120 to 140 days. The crop productivity in India was reported to be between $300-500 \mathrm{~kg} \mathrm{ha}^{-1}$. However, little information is available about the crop's suitability and productivity in the
Coastal Humid Tropic of India where winter is mild and length of growing period in winter is between 80 to 120 days. The present investigation was initiated to address the several issues related to introduction of the crop in the Coastal Humid Tropic. The attempt was foreseen as a prelude to successful introduction, would allow wider choice of crops during winter growing season (rabi). The crop is recognized as a potential component in crop diversification in recent years (Ahmad et al., 2007). The responses of the crop to sowing window, plant density, pests and diseases, nutrient and soil management are very important for the successful introduction in newer areas. Productivity estimates and factors affecting productivity are also vital for assessing the crop performance and fine tuning the resource management in newer areas. Nigella is a long day plant and interaction with the sowing window is crucial in the success of the crop. Further, optimal crop stand and its interaction with season influences the geo-spatial adjustment of the plant, finally yield attributes and yield. The relationship of yield and spacing is complex is generally spreads in normal distribution unless otherwise special interventions are taken up. So, optimization of plant population to a particular plane is very important for realizing maximum productivity of the crop. The medicinal use of the crop superseded the spice use, thus quality has attained supreme status. Sowing window, crop geometry and nutrient management are critical factors that affect quality in a great span. Assessment of quality, in newer areas of introduction, is not only essential but also critical in promoting the crop in a large way (Wiersum et al., 2006). The success of any new introduction depends on the available scientific wisdom and crop performance data to a large extent. Often, lack of such data prevents successful establishment of the crop beyond the preliminary evaluation sites. In view of the neophytic nature of the crop in 
Coastal Humid Tropic of India, a systematic study on the effect of date of sowing and plant densities on growth, yield and quality of nigella was under taken during winter growing season (rabi).

\section{Materials and Methods}

The present investigation was conducted during winter seasons of 2012-13 and 201314 at Horticultural Research Station, Lam (Andhra Pradesh), India. The experimental site is situated at an altitude of 31.5 meters above mean sea level, $16^{\circ} 18^{\prime} \mathrm{N}$ latitude, $80^{\circ}$ 29' E longitude in the Coastal Humid Tropic Agro-climatic Zone, India. The experimental soil belongs to the textural class of clay soil (vertisols), slightly alkaline in reaction $(\mathrm{pH}$ 7.6), low in available organic carbon (0.35\%) and nitrogen (231.5 $\left.\mathrm{kg} \mathrm{ha}^{-1}\right)$, medium in phosphorous (29.5 $\left.\mathrm{kg} \mathrm{ha}^{-1}\right)$ and high in available potassium (675.5 $\mathrm{kg} \mathrm{ha}^{-1}$ ) (Table 1). The $\mathrm{pH}$ of irrigation water was 7.3 and EC was $0.56 \mathrm{dS} \mathrm{m}^{-1}$. The experiment was laid out in split plot design and replicated three times. The dates of sowing were taken as the mainplot treatments and plant densities were taken as sub-plot treatments. The seeds were dibbled at a depth of $1.5 \mathrm{~cm}$ in rows of desired spacing as per the treatment. A seed rate of $5 \mathrm{~kg} \mathrm{ha}^{-1}$ was used for sowing the crop. Two days prior to sowing, half the dose of $\mathrm{N}$ $\left(20 \mathrm{~kg} \mathrm{ha}^{-1}\right)$ and full dose of phosphorus (20 $\left.\mathrm{kg} \mathrm{ha}{ }^{-1}\right)$ and potassium $\left(20 \mathrm{~kg} \mathrm{ha}^{-1}\right)$ were applied as basal application and was properly mixed with the soil. Remaining half dose of nitrogen $\left(20 \mathrm{~kg} \mathrm{ha}^{-1}\right.$ ) was applied as top dressing at 35 days after sowing (DAS). The crop was irrigated at 10 days interval depending upon the moisture condition of the experimental plot to maintain uniform soil moisture throughout the crop growth period. Regular weeding and plant protection measures were taken up to protect the crop from weed competition and pest incidence. Observations on germination, field emergence, plant growth, yield attributes, yield and quality parameters were recorded. The essential (volatile) oil content in the seed was determined by hydro-distillation according to AOAC (2000) standard method (962.17). The seed oil content was determined using the Soxhlet extraction according to the official method (AOAC, 2000). The seed protein content was assayed using the Lowry protocol based on Folin reaction (Lowry et al., 1951). The total carbohydrate in the seed was estimated using the Phenol Sulphuric acid method (Krishnaveni et al., 1984). The crude fibre content was estimated as per procedure in AOAC (2000) Method No. 3210. Statistical analysis for the data was done following the analysis of variance technique for split plot design as suggested by Gomez and Gomez (1984). Statistical significance was tested by applying F-test at 0.05 level of probability. Critical differences were calculated for the metric parameters and the traits found significant $(\mathrm{p} \leq 0.05)$ were compared for the effects of different treatments.

\section{Results and discussion}

\section{Weather during investigation}

The weekly mean maximum temperatures (mean of 2012 and 2013 years) ranged from 29.1 to $34.8^{\circ} \mathrm{C}$ during the investigation period. The mean minimum temperature ranged from 16.2 to $25.4^{\circ} \mathrm{C}$. The weekly mean relative humidity (morning) ranged from 42 to $88.5 \%$ (Figure 1).

\section{Field emergence and plant growth}

The different dates of sowing had no influence on the germination of nigella seed, which varied between 94.8 to $96.7 \%$ (Data not presented). However, lower field emergence was observed in the crop sown beyond $1^{\text {st }}$ fortnight of November. The dates 
of sowing and plant densities had significant influence on the morphological, growth, yield and quality attributes. The interaction was non-significant for all the characters studied. Shorter plants with less number of leaves and branches were recorded when the crop sown beyond $1^{\text {st }}$ fortnight of November (Table 2). Similarly the plant density of 50 plants $\mathrm{m}^{-2}$ recorded significantly lower number of leaves and number of branches per plant (Table 2).

The growth indices Leaf Area Index (LAI) and Crop Growth Rate (CGR) at 30, 60 and 90 DAS were on par in the first three dates of sowing and then declined significantly. LAI and CGR at 30, 60 and 90 DAS were significantly highest in the crop sown at 50 plants $\mathrm{m}^{-2}$ density (Table 2). Fresh and dry matter accumulation at different growth stages in the first three dates of sowings was on par, and then declined significantly (Table 3). Fresh and dry matter accumulation at 30, 60 and 90 DAS was lowest in the plant density of 50 plants $\mathrm{m}^{-2}$. The total leaf chlorophyll content at $50 \%$ flowering was significantly lowest in the crop sown during $1^{\text {st }}$ fortnight of December $\left(2.15 \mathrm{mg} \mathrm{g}^{-1}\right.$ fresh weight) and in the crop sown at 50 plants $\mathrm{m}^{-2}$ density (2.16 $\mathrm{mg} \mathrm{g}^{-1}$ fresh weight) (Table 4). There was a hastening of crop phenology with the delay in sowing as well as increased plant densities (Table 4 and Figure 2). The crop sown during $1^{\text {st }}$ fortnight of December recorded significantly fewer days for maturity (101.1 days). Among different plant densities, the crop sown at 50 plants $\mathrm{m}^{-2}$ density (104.7 days) matured significantly earlier than other plant densities.

\section{Yield attributes}

Yield contributing characters (Table 5) like fresh weight of capsule, capsule weight at harvest, capsule diameter, number of capsules, number of seeds per capsule, test weight, capsule yield per plant, grain yield per plant and husk yield per plant were significantly higher in the crop sown between $1^{\text {st }}$ fortnight of October to $1^{\text {st }}$ fortnight of November than the crop sown during $2^{\text {nd }}$ fortnight of November to $1^{\text {st }}$ fortnight of December. The above attributes were significantly lower in the crop sown at 50 plants $\mathrm{m}^{-2}$ density during the study.

The seed yield $\left(\mathrm{q} \mathrm{ha} \mathrm{h}^{-1}\right)$, stalk yield $\left(\mathrm{g} \mathrm{m}^{-2}\right)$, fixed oil yield $\left(\mathrm{kg} \mathrm{ha}^{-1}\right)$ and essential oil yield $\left(\mathrm{L} \mathrm{ha}^{-1}\right)$ were on par in the first three dates of sowing then declined significantly. Maximum grain yield $\left(789 \mathrm{~kg} \mathrm{ha}^{-1}\right)$, stalk yield $(166.5 \mathrm{~g}$ $\mathrm{m}^{-2}$ ) and essential oil yield (2.89 $\left.1 \mathrm{ha}^{-1}\right)$ was recorded in the crop sown during the $2^{\text {nd }}$ fortnight of October. Seed yield (848 $\left.\mathrm{kg} \mathrm{ha}^{-1}\right)$, stalk yield $\left(197.1 \mathrm{~kg} \mathrm{~m}^{-2}\right)$ and essential oil yield (2.99 $\left.\mathrm{L} \mathrm{ha}^{-1}\right)$ were significantly higher in the crop sown at 50 plants $\mathrm{m}^{-2}$ density. The fixed oil yield recorded in the first three sowings was on par and significantly higher than the sowings during $2^{\text {nd }}$ fortnight of November $\left(247.1 \mathrm{~kg} \mathrm{ha}^{-1}\right)$ and $1^{\text {st }}$ fortnight of December $\left(238.8 \mathrm{~kg} \mathrm{ha}^{-1}\right)$. The fixed oil yield recorded with the crop sown at 50 plants $\mathrm{m}^{-2}$ $\left(299.0 \mathrm{~kg} \mathrm{ha}^{-1}\right)$ and 33.3 plants $\mathrm{m}^{-2}(284.6 \mathrm{~kg}$ $\mathrm{ha}^{-1}$ ) were on par and significantly higher over the observation recorded with 25 plants $\mathrm{m}^{-2}$ $\left(220.8 \mathrm{~kg} \mathrm{ha}^{-1}\right)$.

\section{Quality}

The essential oil and fixed oil contents of the seed were lower in the last two sowings (Table 6). However, the studied plant densities did not impact the essential oil content of the seed. Higher fixed oil content was recorded with the plant density of 25 and 33.33 plants $\mathrm{m}^{-2}$ (36.6 and $36.5 \% \mathrm{w} \mathrm{w}^{-1}$, respectively). Seed protein and carbohydrate contents increased in their proportions with delay in sowing. However, the significantly lowest protein and highest carbohydrate contents were observed in the crop sown at 50 plants $\mathrm{m}^{-2}$ density (179.0 and $326.4 \mathrm{~g} \mathrm{~kg}^{-1}$, 
respectively). The seed moisture, ash and crude fibre contents of seed were not influenced by the dates of sowing, plant densities and their interaction.

The decrease in field emergence observed with delayed sowing might be due to the interference of daily minimum temperatures (ranged between 16.2 to $25.2^{\circ} \mathrm{C}$, during study period) with germination as reported by Ghaderi et al., (2008).

When the crop was sown during second fortnight of November and first fortnight of December, there was a reduction in many growth parameters of the plant. In such late sown crop, lower minimum temperatures during early crop growth, subsequent increase in sunshine hours and light intensities might have caused quick depletion of photosynthetic reserves affecting growth. The availabe photosynthetic active radiation within the crop canopy might also be responsible for reducing the ability of plants to synthesize photosynthates and shortening of crop phenology. Hafez (1998) and Jafari (2013) recorded similar observations in their studies on nigella. The differences in CGR in different dates of sowing were mainly due to the differences in the production of leaves and leaf expansion as indicated by the LAI (Table 3 ). The higher LAI in the early sowing dates improved the photosynthetic capacity and production of assimilates thus contributing to the higher CGR. According to Wolf and Carson (1973), the impact of season on the crop could be critically captured by the growth analysis using CGR, which was also observed in the present investigation. Delayed sowing was reported to have affected the dry matter accumulation negatively in various studies (Moghaddam and Motlagh, 2007; Jafari, 2013). The increase or decrease in LAI has a direct effect on plant growth rate as it represents the photosynthesis capacity and assimilates production of the crop per unit area (Watson, 1958), which is influenced by the season of crop growth. The significant reduction in LAI in the last two dates of sowing indicated the decreasing capacity of the crop to produce photosynthates due to influence of climatic variations during the crop season. Ganjali and Yadegari (2008) reported significant reduction in LAI with delay in sowing of nigella.

Fig.1 Meteorological data (Mean) during the experimentation

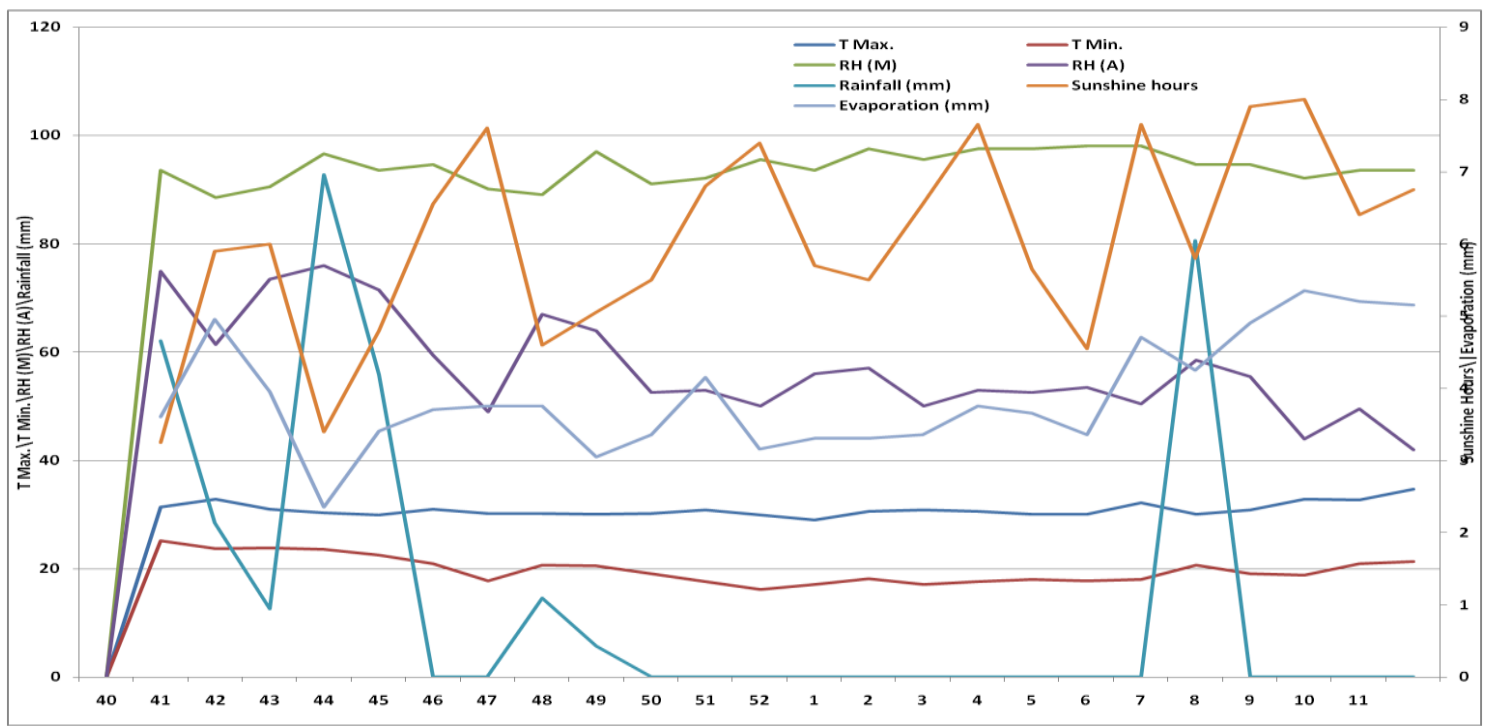


Fig.2 Gantt chart of duration (days) taken for various phases of crop phenology

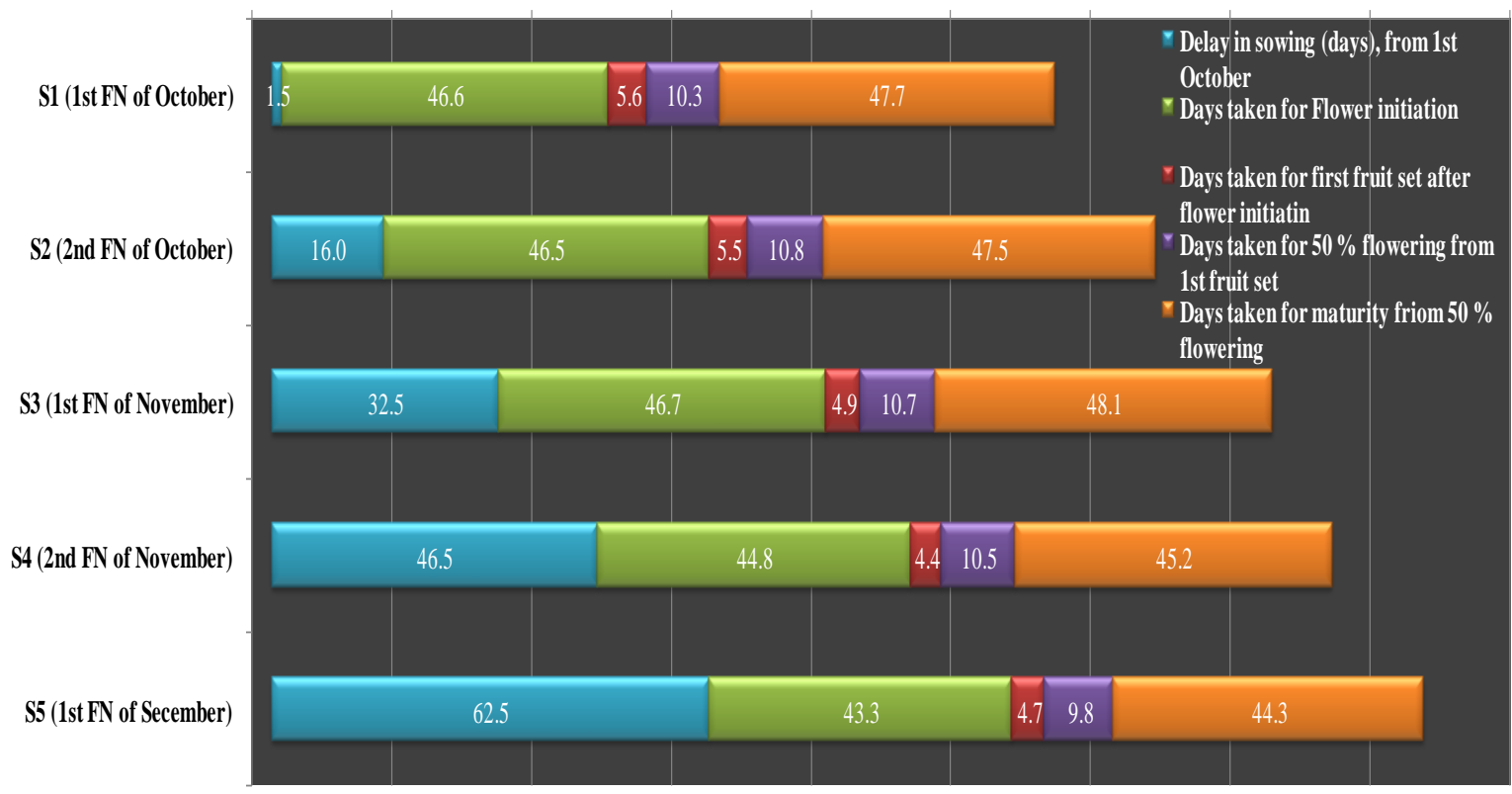

Table.1 Physical and chemical properties of the experimental soil

\begin{tabular}{lll}
\hline S. No. & Particulars & Value \\
\hline I & Mechanical Analysis & \\
& Sand (\%) & 24.0 \\
& Silt (\%) & 18.0 \\
& Clay (\%) & 58.0 \\
& Textural class & Clay \\
\hline II & Physical Properties & \\
& Bulk density (gm cm $\left.{ }^{-3}\right)$ & 1.22 \\
& Water Holding Capacity $(\%)$ & 47.0 \\
& Porosity (\%) & 0.45 \\
& Hydraulic conductivity $\left(\mathrm{cm} \mathrm{hour}^{-1)}\right.$ & 1.4 \\
\hline III & Physico-chemical properties & 7.6 \\
& Soil pH & 0.26 \\
& Electrical conductivity $\left(\mathrm{dS} \mathrm{m}^{-1}\right.$ at $\left.2{ }^{\mathrm{O}} \mathrm{C}\right)$ & 0.53 \\
\hline CEC (me g & \\
& Chemical properties & 0.35 \\
& Organic Carbon $(\%)$ & 231.5 \\
& Available Nitrogen $\left(\mathrm{kg} \mathrm{ha}^{-1}\right)$ & 30.0 \\
& Available Phosphorus $\left(\mathrm{kg} \mathrm{ha}^{-1}\right)$ & 675.5 \\
\hline & Available Potassium $\left(\mathrm{kg} \mathrm{ha}^{-1}\right)$ & \\
& &
\end{tabular}


Table.2 Influence of dates of sowing and plant densities on field emergence, plant height (cm), number of leaves and branches

\begin{tabular}{|c|c|c|c|c|c|c|c|c|c|c|c|c|}
\hline \multirow{3}{*}{ Treatment } & \multirow{3}{*}{$\begin{array}{l}\text { Field } \\
\text { emergence } \\
(\%)\end{array}$} & \multicolumn{4}{|c|}{ Plant height $(\mathrm{cm})$} & \multicolumn{3}{|c|}{ Number of leaves } & \multicolumn{4}{|c|}{ Number of branches } \\
\hline & & 30 & 60 & 90 & & 30 & 60 & 90 & 30 & 60 & 90 & \\
\hline & & DAS & DAS & DAS & Harvest & DAS & DAS & DAS & DAS & DAS & DAS & Harvest \\
\hline \multicolumn{13}{|l|}{ Date of sowing } \\
\hline $\mathrm{S}_{1}\left(1^{\mathrm{st}} \mathrm{FN}\right.$ of October $)$ & $95.8(73.6)$ & 16.2 & 34.6 & 42.4 & 42.8 & 10.5 & 42.6 & 43.8 & 0.68 & 7.5 & 8.4 & 8.8 \\
\hline $\mathrm{S}_{2}\left(2^{\text {nd }}\right.$ FN of October $)$ & $95.8(73.7)$ & 15.8 & 33.5 & 42.3 & 42.0 & 10.4 & 43.1 & 44.8 & 0.62 & 7.5 & 8.5 & 8.9 \\
\hline $\mathrm{S}_{3}\left(1^{\text {st }} \mathrm{FN}\right.$ of November $)$ & $96.3(74.9)$ & 16.0 & 33.4 & 42.2 & 41.8 & 10.6 & 42.9 & 45.6 & 0.60 & 7.4 & 8.3 & 8.7 \\
\hline $\mathrm{S}_{4}\left(2^{\mathrm{nd}} \mathrm{FN}\right.$ of November $)$ & $93.2(68.8)$ & 14.7 & 32.1 & 35.0 & 36.3 & 8.9 & 38.6 & 39.3 & 0.55 & 6.7 & 7.6 & 7.6 \\
\hline $\mathrm{S}_{5}\left(1^{\text {st }} \mathrm{FN}\right.$ of December $)$ & $91.7(66.5)$ & 14.0 & 31.9 & 35.0 & 36.4 & 8.7 & 38.0 & 37.6 & 0.55 & 6.4 & 7.3 & 7.7 \\
\hline $\mathrm{CD}(\mathrm{p}=0.05)$ & 3.43 & 1.13 & NS & 2.26 & NS & 0.75 & 1.48 & 2.87 & $\mathrm{NS}$ & 0.54 & NS & 0.69 \\
\hline \multicolumn{13}{|l|}{ Plant densities } \\
\hline $\mathrm{D}_{1}\left(50\right.$ plants $\left.\mathrm{m}^{-2}\right)$ & $94.8(72.1)$ & 15.2 & 33.1 & 39.5 & 40.2 & 9.0 & 36.4 & 36.6 & 0.55 & 6.7 & 7.6 & 7.8 \\
\hline $\mathrm{D}_{2}\left(33.3\right.$ plants $\left.\mathrm{m}^{-2}\right)$ & $94.2(70.7)$ & 15.3 & 33.2 & 39.2 & 39.5 & 10.2 & 43.0 & 44.7 & 0.61 & 7.3 & 8.2 & 8.6 \\
\hline $\mathrm{D}_{3}\left(25\right.$ plants $\left.\mathrm{m}^{-2}\right)$ & $94.7(71.8)$ & 15.4 & 33.1 & 39.4 & 39.9 & 10.3 & 43.8 & 45.4 & 0.64 & 7.3 & 8.2 & 8.6 \\
\hline $\mathrm{CD}(\mathrm{p}=0.05)$ & NS & NS & NS & NS & NS & 0.4 & 1.18 & 1.26 & $\mathrm{NS}$ & 0.3 & 0.35 & 0.36 \\
\hline
\end{tabular}

Table.3 Influence of dates of sowing and plant densities on leaf area index, crop growth rate, fresh and dry matter accumulation

\begin{tabular}{|c|c|c|c|c|c|c|c|c|c|c|c|c|}
\hline \multirow{3}{*}{ Treatment } & \multicolumn{3}{|c|}{ Leaf Area Index } & \multicolumn{3}{|c|}{$\begin{array}{l}\text { Crop Growth Rate } \\
\qquad\left(\mathrm{g} \mathrm{m}^{-2} \mathrm{day}^{-1}\right)\end{array}$} & \multicolumn{3}{|c|}{$\begin{array}{c}\text { Fresh matter of } \\
\text { aerial part }\left(\mathrm{g} \text { plant }^{-1}\right)\end{array}$} & \multicolumn{3}{|c|}{$\begin{array}{c}\text { Dry weight of } \\
\text { aerial part }\left(\mathrm{g} \text { plant }{ }^{-1}\right)\end{array}$} \\
\hline & 30 & 60 & 90 & 30 & 60 & 90 & 30 & 60 & 90 & 30 & 60 & 90 \\
\hline & DAS & DAS & DAS & DAS & DAS & DAS & DAS & DAS & DAS & DAS & DAS & DAS \\
\hline \multicolumn{13}{|l|}{ Date of sowing } \\
\hline $\mathrm{S}_{1}\left(1^{\mathrm{st}} \mathrm{FN}\right.$ of October $)$ & 0.24 & 0.51 & 0.59 & 0.55 & 2.67 & 4.26 & 3.7 & 10.6 & 13.5 & 0.47 & 2.67 & 6.24 \\
\hline $\mathrm{S}_{2}\left(2^{\text {nd }} \mathrm{FN}\right.$ of October $)$ & 0.25 & 0.52 & 0.62 & 0.57 & 2.72 & 4.25 & 3.7 & 10.7 & 13.5 & 0.47 & 2.72 & 6.32 \\
\hline $\mathrm{S}_{3}\left(1^{\mathrm{st}} \mathrm{FN}\right.$ of November $)$ & 0.24 & 0.51 & 0.60 & 0.55 & 2.67 & 4.16 & 3.6 & 10.6 & 13.5 & 0.46 & 2.67 & 6.19 \\
\hline $\mathrm{S}_{4}\left(2^{\text {nd }} \mathrm{FN}\right.$ of November $)$ & 0.22 & 0.47 & 0.55 & 0.52 & 2.36 & 3.86 & 3.4 & 9.8 & 12.6 & 0.43 & 2.36 & 5.67 \\
\hline $\mathrm{S}_{5}\left(1^{\text {st }} \mathrm{FN}\right.$ of December $)$ & 0.21 & 0.47 & 0.54 & 0.51 & 2.36 & 3.67 & 3.4 & 9.7 & 12.5 & 0.42 & 2.36 & 5.52 \\
\hline $\mathrm{CD}(\mathrm{p}=0.05)$ & 0.01 & 0.02 & 0.03 & 0.02 & 0.21 & 0.26 & 0.16 & NS & 0.64 & 0.02 & NS & 0.27 \\
\hline \multicolumn{13}{|l|}{ Plant densities } \\
\hline $\mathrm{D}_{1}\left(50\right.$ plants $\left.\mathrm{m}^{-2}\right)$ & 0.32 & 0.62 & 0.74 & 0.72 & 2.81 & 4.63 & 3.4 & 9.3 & 12.2 & 0.43 & 2.19 & 5.12 \\
\hline $\mathrm{D}_{2}\left(33.3\right.$ plants $\left.\mathrm{m}^{-2}\right)$ & 0.22 & 0.49 & 0.57 & 0.51 & 2.67 & 4.23 & 3.6 & 10.6 & 13.5 & 0.46 & 2.68 & 6.38 \\
\hline $\mathrm{D}_{3}\left(25\right.$ plants $\left.\mathrm{m}^{-2}\right)$ & 0.16 & 0.38 & 0.44 & 0.39 & 2.18 & 3.25 & 3.6 & 11.0 & 13.6 & 0.46 & 2.81 & 6.46 \\
\hline $\mathrm{CD}(\mathrm{p}=0.05)$ & 0.01 & 0.02 & 0.02 & 0.01 & 0.12 & 0.18 & 0.12 & 0.35 & 0.23 & 0.01 & 0.14 & 0.18 \\
\hline
\end{tabular}


Table.4 Influence of dates of sowing and plant densities on chlorophyll, phenology, number of capsules, capsule weight and size

\begin{tabular}{|c|c|c|c|c|c|c|c|c|c|c|}
\hline \multirow{2}{*}{ Treatment } & \multirow{2}{*}{$\begin{array}{l}\text { Chlorophyll } \\
\quad\left(\mathrm{mg} \mathrm{g}^{-1}\right)\end{array}$} & \multicolumn{4}{|c|}{ Number of days to } & \multirow{2}{*}{$\begin{array}{c}\text { Number } \\
\text { of } \\
\text { capsules } \\
\text { plant }\end{array}$} & \multicolumn{2}{|c|}{$\begin{array}{l}\text { Capsule weight } \\
\left(\mathrm{g} \mathrm{fruit}^{-1}\right)\end{array}$} & \multicolumn{2}{|c|}{ Capsule } \\
\hline & & $\begin{array}{c}\text { Flower } \\
\text { initiation }\end{array}$ & $\begin{array}{l}\text { First } \\
\text { fruit }\end{array}$ & $\begin{array}{c}50 \% \\
\text { flowering }\end{array}$ & Maturity & & Fresh & Harvest & $\begin{array}{l}\text { Length } \\
(\mathrm{cm})\end{array}$ & $\begin{array}{c}\text { Diameter } \\
(\mathrm{cm})\end{array}$ \\
\hline \multicolumn{11}{|l|}{ Dates of sowing } \\
\hline $\mathrm{S}_{1}\left(1^{\mathrm{st}} \mathrm{FN}\right.$ of October $)$ & 2.41 & 46.55 & 52.1 & 62.4 & 110.1 & 18.2 & 0.72 & 0.23 & 1.05 & 0.86 \\
\hline $\mathrm{S}_{2}\left(2^{\mathrm{nd}} \mathrm{FN}\right.$ of October $)$ & 2.44 & 46.50 & 51.9 & 62.7 & 110.2 & 19.0 & 0.74 & 0.24 & 1.06 & 0.87 \\
\hline $\mathrm{S}_{3}\left(1^{\mathrm{st}} \mathrm{FN}\right.$ of November $)$ & 2.43 & 46.68 & 51.6 & 62.3 & 110.4 & 17.4 & 0.71 & 0.24 & 1.05 & 0.86 \\
\hline $\mathrm{S}_{4}\left(2^{\text {nd }} \mathrm{FN}\right.$ of November $)$ & 2.29 & 44.77 & 49.1 & 59.6 & 104.8 & 14.1 & 0.66 & 0.22 & 1.00 & 0.81 \\
\hline $\mathrm{S}_{5}\left(1^{\mathrm{st}} \mathrm{FN}\right.$ of December $)$ & 2.15 & 43.33 & 48.0 & 57.8 & 102.1 & 13.1 & 0.64 & 0.22 & 0.99 & 0.79 \\
\hline $\mathrm{CD}(\mathrm{p}=0.05)$ & 0.04 & 0.4 & 0.86 & 0.7 & 2.01 & 1.86 & 0.05 & 0.01 & NS & 0.04 \\
\hline \multicolumn{11}{|l|}{ Plant densities } \\
\hline $\mathrm{D}_{1}\left(50\right.$ plants $\left.\mathrm{m}^{-2}\right)$ & 2.16 & 43.93 & 48.8 & 59.0 & 104.7 & 10.9 & 0.64 & 0.19 & 1.01 & 0.81 \\
\hline $\mathrm{D}_{2}\left(33.3\right.$ plants $\left.\mathrm{m}^{-2}\right)$ & 2.40 & 46.37 & 51.5 & 61.7 & 108.8 & 19.1 & 0.72 & 0.25 & 1.04 & 0.84 \\
\hline $\mathrm{D}_{3}\left(25\right.$ plants $\left.\mathrm{m}^{-2}\right)$ & 2.46 & 46.39 & 51.4 & 62.3 & 109.1 & 19.0 & 0.72 & 0.25 & 1.04 & 0.86 \\
\hline$C D(p=0.05)$ & 0.04 & 0.56 & 0.56 & 0.56 & 0.85 & 0.82 & 0.02 & 0.01 & 0.02 & 0.02 \\
\hline
\end{tabular}

Table.5 Influence of dates of sowing and plant densities on number of seeds per capsule, test weight and yield parameters

\begin{tabular}{|c|c|c|c|c|c|c|c|c|}
\hline Treatment & $\begin{array}{c}\text { Number of } \\
\text { seeds per } \\
\text { capsule }\end{array}$ & $\begin{array}{l}\text { Test weight } \\
(\text { g } 1000 \\
\left.\text { seed }^{-1}\right)\end{array}$ & $\begin{array}{l}\text { Capsule } \\
\text { yield (g } \\
\left.\text { plant }^{-1}\right)\end{array}$ & $\begin{array}{l}\text { Seed yield } \\
\text { per plant }(\mathrm{g})\end{array}$ & $\begin{array}{l}\text { Husk yield } \\
\text { per plant (g) }\end{array}$ & $\begin{array}{l}\text { Stalk yield } \\
\quad\left(\mathrm{g} \mathrm{m}^{-2}\right)\end{array}$ & $\begin{array}{l}\text { Seed yield } \\
\left(\mathrm{kg} \mathrm{ha}^{-1}\right)\end{array}$ & $\begin{array}{c}\text { Harvest } \\
\text { Index }\end{array}$ \\
\hline \multicolumn{9}{|l|}{ Date of sowing } \\
\hline $\mathrm{S}_{1}\left(1^{\mathrm{st}} \mathrm{FN}\right.$ of October $)$ & 63.2 & 1.68 & 3.8 & 2.2 & 1.6 & 161.1 & 777.0 & 0.33 \\
\hline $\mathrm{S}_{2}\left(2^{\mathrm{nd}} \mathrm{FN}\right.$ of October $)$ & 64.3 & 1.71 & 3.9 & 2.2 & 1.7 & 166.5 & 789.0 & 0.33 \\
\hline $\mathrm{S}_{3}\left(1^{\mathrm{st}} \mathrm{FN}\right.$ of November $)$ & 63.5 & 1.67 & 3.8 & 2.2 & 1.6 & 161.4 & 761.5 & 0.32 \\
\hline $\mathrm{S}_{4}\left(2^{\text {nd }} \mathrm{FN}\right.$ of November $)$ & 59.1 & 1.57 & 3.4 & 2.0 & 1.4 & 147.8 & 703.5 & 0.33 \\
\hline $\mathrm{S}_{5}\left(1^{\mathrm{st}} \mathrm{FN}\right.$ of December $)$ & 59.2 & 1.54 & 3.3 & 1.9 & 1.4 & 146.8 & 683.5 & 0.32 \\
\hline $\mathrm{CD}(\mathrm{p}=0.05)$ & 1.06 & 0.05 & 0.14 & 0.09 & 0.06 & 5.74 & 23.8 & NS \\
\hline \multicolumn{9}{|l|}{ Plant densities } \\
\hline $\mathrm{D}_{1}\left(50\right.$ plants $\left.\mathrm{m}^{-2}\right)$ & 60.4 & 1.56 & 2.9 & 1.7 & 1.2 & 197.1 & 848.0 & 0.30 \\
\hline $\mathrm{D}_{2}\left(33.3\right.$ plants $\left.\mathrm{m}^{-2}\right)$ & 62.5 & 1.66 & 4.0 & 2.3 & 1.7 & 155.3 & 778.0 & 0.33 \\
\hline $\mathrm{D}_{3}\left(25\right.$ plants $\left.\mathrm{m}^{-2}\right)$ & 62.7 & 1.68 & 4.1 & 2.4 & 1.7 & 117.8 & 602.0 & 0.34 \\
\hline $\mathrm{CD}(\mathrm{p}=0.05)$ & 0.97 & 0.03 & 0.11 & 0.06 & 0.06 & 3.67 & 24.4 & 0.01 \\
\hline
\end{tabular}


Table.6 Influence of dates of sowing and plant densities on essential oil yield, fixed oil yield and seed quality

\begin{tabular}{|c|c|c|c|c|c|c|c|c|c|}
\hline \multirow{3}{*}{ Treatment } & Essential & Fixed oil & Essential oil & Fixed oil & Protein & Carbohydrate & Moisture & Ash & Cruder \\
\hline & oil yield & yield (kg & content & content & content & content $\left(\mathrm{g} \mathrm{kg}^{-1}\right)$ & content & $\left(\% \mathrm{w} \mathrm{w}^{-}\right.$ & fibre \\
\hline & $\left(\mathrm{L} \mathrm{ha}^{-1}\right)$ & $\left.\mathrm{ha}^{-1}\right)$ & $\left(\% \mathrm{v} \mathrm{w}^{-1}\right)$ & $\left(\% \mathrm{w} \mathrm{w}^{-1}\right)$ & $\left(\mathrm{g} \mathrm{kg}^{-1}\right)$ & & $\left(\% \mathrm{w} \mathrm{w}^{-1}\right)$ & $\left.{ }^{1}\right)$ & $\left(\% \mathrm{w} \mathrm{w}^{-1}\right)$ \\
\hline \multicolumn{10}{|l|}{ Date of sowing } \\
\hline $\mathrm{S}_{1}\left(1^{\mathrm{st}} \mathrm{FN}\right.$ of October $)$ & 2.84 & 290.6 & $0.37(0.21)$ & 36.9 & 179.0 & 293.4 & 7.6 & 4.8 & 5.13 \\
\hline $\mathrm{S}_{2}\left(2^{\text {nd }} \mathrm{FN}\right.$ of October $)$ & 2.89 & 285.3 & $0.37(0.21)$ & 36.8 & 181.9 & 295.0 & 7.6 & 4.8 & 5.12 \\
\hline $\mathrm{S}_{3}\left(1^{\mathrm{st}} \mathrm{FN}\right.$ of November $)$ & 2.76 & 279.0 & $0.36(0.21)$ & 36.7 & 184.6 & 300.6 & 7.7 & 4.9 & 5.10 \\
\hline $\mathrm{S}_{4}\left(2^{\text {nd }} \mathrm{FN}\right.$ of November $)$ & 2.43 & 247.1 & $0.34(0.20)$ & 35.1 & 196.1 & 324.1 & 7.6 & 4.8 & 5.13 \\
\hline $\mathrm{S}_{5}\left(1^{\mathrm{st}} \mathrm{FN}\right.$ of December $)$ & 2.24 & 238.8 & $0.33(0.19)$ & 35.0 & 197.5 & 330.0 & 7.2 & 4.8 & 5.11 \\
\hline $\mathrm{CD}(\mathrm{p}=0.05)$ & 0.08 & 15.7 & 0.01 & 0.51 & 8.24 & 15.63 & NS & NS & NS \\
\hline \multicolumn{10}{|l|}{ Plant densities } \\
\hline $\mathrm{D}_{1}\left(50\right.$ plants $\left.\mathrm{m}^{-2}\right)$ & 2.99 & 299.0 & $0.35(0.2)$ & 35.2 & 179.0 & 326.4 & 7.5 & 4.8 & 5.12 \\
\hline $\mathrm{D}_{2}\left(33.3\right.$ plants $\left.\mathrm{m}^{-2}\right)$ & 2.78 & 284.6 & $0.36(0.2)$ & 36.5 & 191.5 & 300.6 & 7.6 & 4.8 & 5.11 \\
\hline $\mathrm{D}_{3}\left(25\right.$ plants $\left.\mathrm{m}^{-2}\right)$ & 2.12 & 220.8 & $0.35(0.2)$ & 36.6 & 192.9 & 298.9 & 7.5 & 4.8 & 5.12 \\
\hline $\mathrm{CD}(\mathrm{p}=0.05)$ & 0.09 & 9.5 & NS & 0.57 & 4.08 & 10.54 & NS & NS & NS \\
\hline
\end{tabular}


The decrease in leaf number, branches, fresh and dry matter accumulation and increase in LAI and CGR with the increase in plant density might be due to inter-plant competition for various critical resources like growing space, water, nutrients and light. Various studies indicated that the increase in plant densities affected number of branches (Tuncturk et al., 2005), leaf number (Ayub et al., 2008), fresh and dry matter accumulation (Bahraminezhad and Papzan, 2006), LAI and CGR (Mollafilabi et al., 2009).

The higher capsule number per plant, weight, size, seeds per capsule, test weight of seed and grain yield with early sowing might be due to increased availability of photosynthates which is substantiated by the higher LAI and CGR in the crop sown between $1^{\text {st }}$ fortnights of October to $1^{\text {st }}$ fortnight of November (Tables 2 to 6).

Reduced growth and yield in delayed sowing was attributable to changes in the radiation, sunlight hours and temperature which are unfavourable to the crop. The advantage of suitable season and time of sowing is irreplaceable with any other agronomic management. The advantage of suitable time of sowing was reported in different farming situations (D'Antuono et al., 2002; Talafih et al., 2007; Malhotra and Vashishtha, 2008; Kadhum, 2009; Majumder et al., 2012; Islam and Akhtar, 2013; Vaseghi et al., 2013).

The decline in fixed oil yield with the crop sown beyond $1^{\text {st }}$ fortnight of November may be due to unfavourable climate experienced by the crop for biosynthesis of fats. The increase in essential oil yield with early sowing might be due to the favourable meteorological inputs which enhanced the essential oil biosynthesis resulting in more plant metabolites. According to El-Mekawy (2012), essential oil content is always higher when the crop is sown early.
The decrease in capsule number per plant, weight, size, seeds per capsule, test weight of seed and grain yield per plant with increased plant density might be due to the decreased reserve of photosynthates owing to inter and intra-plant competition for various resources. At higher populations, inter and intra-plant competition between vegetative and reproductive organs for assimilates intensifies and since reproductive buds are formed later than vegetative buds, the adverse effects of intensified competition impacts reproductive buds at the first place. On the other hand, the increased plant density increases respiration and decreases photosynthesis which leads to the decrease in the transfer of assimilates to seeds and consequently, seed yield loss. The plant density at spacing of $20 \times 10 \mathrm{~cm}(50$ plants $\mathrm{m}^{-2}$ ) was more effective and gave significantly higher grain yield per hectare than the two other plant densities and was, therefore, most suitable for obtaining maximum yields.

The higher seed yield per hectare was due to the higher capsule density per unit area of land. Higher fixed oil and essential oil yields observed with increased plant density were due to incremental contribution of individual plants to total yield. The negative influence of higher plant densities on capsule weight (Gholinezhad and Abdolrahimi, 2014), capsule number (Akbarian et al., 2013), seeds per capsule (Meena et al., 2011), test weight (Ellatif, 2008) and yield per plant (Jafari, 2013) were reported in nigella. The increase in grain yield (Melkie et al., 2008; Abdolrahimi et al., 2012), essential oil yield (El-Mekawy, 2012) and fixed oil yield (Moosazadeh and Baradaran, 2011; Shabestari and Moradi, 2013) due to variation in plant densities was reported in different farming situations.

The biosynthesis of essential oils is highly integrated with the physiology of the whole 
plant and so depends on the metabolic state and preset developmental differentiation programme of the synthesizing tissue, which is environment dependent (Sangwan et al., 2001). Environmental factors such as light, temperature, and moisture status can greatly influence the emission of volatiles and the yield and composition of essential oils (Dudareva, 2004).

The differences in the essential oil content due to the time of sowing may be due to the differences in light, temperature and relative humidity which prevailed during different crop phenological stages in each sowing. The essential oil content was reported to vary with the growing season (Kizil et al., 2008) and time of sowing (Hafez, 1998 and El-Mekawy, 2012)

Fixed oil in germinating seed serves as an energy reserve and source of carbon precursors. Lipid content and lipid composition may vary with environmental conditions which may be adaptive or a mere change in enzymatic activity without appreciable significance to the plant physiology of the plant (Kuiper, 1985).

The changes are often depending on enzymatic activity in the lipid environment. Season of crop growth affects not only the composition of fatty acids, but also the rate and quantity of the lipid production (Mazliak, 1988).

The higher fixed oil content with early sowing may be due to improved dry matter production and enhanced source capacity which might have improved the translocation of photo-assimilates to sink, thus promoting the biosynthesis of oil. These results are in accordance with those of Hafez (1988), D'Antuono (2002), Kizil et al., (2008) and ElMekawy (2012). The decrease in fixed in oil content with increased plant population may be due to its role in resource availability and allocation within the plant, thus affecting the biosynthesis and accumulation of fats in the seed. The decrease in fixed oil content with higher plant densities was reported by Meena et al., (2011), Moosazadeh and Baradaran (2011), Shabestari and Moradi (2013) and Gholinezhad and Abdolrahimi (2014).

The lower protein content in the early crop may be due to the influence of environmental factors, such as photoperiod and temperature which may not be optimum for protein synthesis, while the same factors were favourable in the late sown crop. The higher protein content in widely spaced crop was probably due to the more availability of resources such as nutrients, water and light which might have promoted the synthesis of proteins.

The lower carbohydrate content in the early crop may be due to environmental factors favourable for utilization of carbohydrates for other purposes such as lipid production which might have reduced the content in the seed. The higher carbohydrate content in closely spaced crop was probably due to inefficient utilization of carbohydrates for biosynthesis of lipids. The lowering protein content and the increase in carbohydrate content with increase in plant population were reported by Hammo (2008).

The different dates of sowing had significant influence on growth and yield of nigella. In the winter crop, delay in sowing caused reduction in growth, yield and quality. The optimum sowing time in Coastal Humid Tropic of India was found to be between $1^{\text {st }}$ fortnights of October to $1^{\text {st }}$ fortnight of November, sowing beyond this period had undesirable effects on the crop. Plant densities had significant effect on plant growth and quality of nigella. 
The individual growth parameters of the crop were lowest in the crop sown with 50 plants $\mathrm{m}^{-2}$. However, grain, fixed oil and essential oil yields were higher in the density of 50 plants $\mathrm{m}^{-2}$. Maximum seed yield $\left(\mathrm{kg} \mathrm{ha}^{-1}\right)$, stalk yield $\left(\mathrm{g} \mathrm{m}^{-2}\right)$, fixed oil yield $\left(\mathrm{kg} \mathrm{ha}^{-1}\right)$ and essential oil yield $\left(\mathrm{L} \mathrm{ha}^{-1}\right)$ were recorded in the first three dates of sowing (sowing window between $1^{\text {st }}$ fortnight of October to $1^{\text {st }}$ fortnight of November) at 50 plants $\mathrm{m}^{-2}$ density.

\section{References}

Abdolrahimi, B., P. Mehdikhani and Tappe, A.H.G. 2012. The effect of harvest index, yield and yield components of three varieties of black seed (Nigella sativa) in different planting densities. International Journal of Agri. Science. 2 (1): 93-101.

Ahmad, Z., A. Ghafoor, S. Ochatt and Jain, S.M. 2007. Nigella sativa-a potential commodity in crop diversification traditionally used in healthcare. In: Introduction of Medicinal Herbs and Spices as Crops. Ministry of Food, Agriculture and Livestock, Pakistan. pp. 1-34.

Akbarian, M.A., M.T. Darzi and Hadi, M.H.S. 2013. Effects of Nitroxin and plant density on grain yield and yield components of black cumin (Nigella sativa). International Research Journal of Applied and Basic Sciences. 4 (11):34503457.

AOAC. 2000. Official methods of analysis of AOAC International (17th Ed.). Maryland, USA: AOAC.

Ayub, M., M.A. Nadeem, A, Tanveer, M. Tahir, M.T.Y. Saqib and Nawaz, R. 2008. Effect of different sowing methods and times on the growth and yield of fennel (Foeniculum vulgare Mill). Pak. J. Bot. 40 (1): 259-264.

Bahraminezhad, S., and Papzan, A.A.H. 2006. Effect of row spacing on different characteristics of black cumin (Nigella sativa L.) under Kermanshah conditions.
Iranian Journal of Crop Sciences. 8 (3): 249-241.

D'Antuono, L.F., A. Moretti and Lovato, A.F.S. 2002. Seed yield, yield components, oil content and essential oil content and composition of Nigella sativa L. and Nigella damascena L. Industrial Crops and Products. 15: 59-69.

Dudareva, N., E. Pichersky and Gershenzon, J. 2004. Biochemistry of plant volatiles. Plant Physiology. 135 (4): 1893-1902.

Ellatif, M.Z.M.A., 2008. Effect of planting density, biofertilizers and micronutrients on Nigella sativa. Ph.D. Minia University, Egypt.

El-Mekawy, M.A.M., 2012. Growth and yield of Niglla sativa L. plant influenced by sowing date and irrigation treatments. American-Eurasian J. Agric. Environ. Sci. 12 (4): 499-505.

Ganjali, H., and Yadegari, M. 2008. Evaluation Yield Components and Essence of Nigella Sativa with Different Time of Cultivation and Density. Proceedings of $5^{\text {th }}$ International Crop Science Congress held at Jeju, Korea April 13-18, 2008. 1113.

Ghaderi, F.A., A. Soltani and Sadeghipour, H.R. 2008. Cardinal Temperatures of Germination in Medicinal Pumpkin (Cucurbita pepo convar. pepo var. styriaca), Borago (Borago officinalis L.) and Black Cumin (Nigella sativa L.). Asian Journal of Plant Sciences. 7 (6): 574-578.

Gholinezhad, E. and Abdolrahimi, B. 2014. The investigation of oil yield of three varieties of black seed (Nigella sativa) in different plant densities. International Journal of Advanced Biological and Biomedical Research. 2 (4): 919-930.

Giridhar, K., S. Surya Kumari, G. Sathyanaryana Reddy and Naram Naidu, L. 2015. Nigella: A Seed Spice of Blessing. Spices India, August, 28 (8): $10-18$.

Gomez, K.A. and Gomez, A.A. 1984. Statistical procedures for Agricultural Research. 
Second Edition. A Wiley inter-Science Publications, John Wiley and Sons, New York, Chichester, Torento, Singapore. $680 \mathrm{p}$.

Hafez, M.H., 1998. Effect of plant density, planting date, nitrogen fertilization sources and some nutrients on growth, flowering, seed yield and oil yield of Nigella sativa L. Plants. Ph.D. Thesis. Minia University, Minya, Egypt.

Hammo, Y.H., 2008. Effect of high levels of nitrogen and phosphorus fertilizer, pinching, and seed rate on growth and yield components of Nigella sativa L. 1Vegetative growth and seed yield. Mesopotamia Journal of Agriculture. 36 (1): 34-32.

Islam, N., and Akhtar, R. 2013. Annual Report 2011-12. Ayub Agricultural Research Institute (AARI). Directorate of Agricultural Information, Punjab, Lahore, Pakistan. 69.

Jafari, A., 2013. The evaluation effects of plant density and sowing dates on yield and yield components of black cumin (Nigella sativa) under Ilam climate condition. In Proceedings of 2nd National Congress on Medicinal Plants, 15 -16 May 2013, Tehran- Iran. 456.

Kadhum, M.H., 2009. Evaluation Yield of Some Varieties of Nigella sativa L. Under Different Climatic Conditions. Al-anbar Journal of Agricultural Sciences. 7 (1): 255-261.

Kizil, S., S. Kirici, Ö. Çakmak and Khawar, K.M. 2008. Effects of sowing periods and $\mathrm{P}$ application rates on yield and oil composition of black cumin (Nigella sativa L.). Journal of Food Agriculture and Environment. 6 (2): 242-246.

Krishnaveni, S., T. Balasubramanian and Sadasivam, S. 1984. Sugar distribution in sweet stalk sorghum. Food Chemistry. 15 (3): 229-232.

Kuiper, P.J.C., 1985. Environmental changes and lipid metabolism of higher plants. Physiologia Plantarum. 64 (1): 118-122.

Lowry, O.H., N.J. Rosebrough, A.L. Farr and
Randall, R.J. 1951. Protein measurement with the Folin phenol reagent. J. Biol. Chem, 193 (1), 265-275.

Majumder, C., A. Pariari, S. Khan and Singh, L.S. 2012. Determination of optimum date of sowing of black cumin (Nigella sativa L.) for Gangetic alluvial plains of West Bengal. In: Proceedings of State level seminar on Production \& Management of spices in West Bengal. Held during 1-2 ${ }^{\text {nd }}$ March, 2012, BCKV, Kalyani.

Malhotra, S.K. and Vashishtha, B.B. 2008. Response of nigella (Nigella sativa L) variety NRCSS AN 1 to different agrotechniques. Journal of Spices and Aromatic Crops. 17 (2): 190-193.

Malhotra, S.K., 2004. Nigella. In: Peter, K.V. (Ed.), Handbook of Herbs and Spices, Woodhead Publishing Ltd., Cambridge, UK. 206-2015.

Mazliak, P., 1988. Environmental Effects on Fatty Acid Quality. In: Pinfield, N. and A. Stobart (Eds.), Plant Lipids: Targets for Manipulation. British Plant Growth Regulator Group, Bristol. Pp. 57-71.

Meena, S.S., M.M. Anwer, R.S. Mehta, G. Lal, K. Kant, Y.K. Sharma, M.K. Vishal, K.L. Jingar and Meena, S.R. 2011. Performance of nigella (Nigella sativa $\mathrm{L}$.) as influenced by sowing dates and crop geometry in semi-arid eco-system. International Journal of Seed Spices. 1 (1): 8-12.

Melkie, Y., A. Yeshanew and Wosen, T. 2008. Effect of seed rate and time of sowing on grain yield of black cumin (Nigella sativa L) in Takusa Woreda, North Gondar Zone. In: Proceedings of the third Annual Regional Conference on Completed Crop Research Activities. ARARI, 2008. 32-34.

Moghaddam, P.R. and Motlagh, M.A. 2005. Agronomical studies of black cumin (Nigella sativa) as new crop in dry and semi dry agricultural system of Iran. In: Proceedings of the IV $^{\text {th }}$ International Congress of Ethnobotany (ICEB 2005), 21-26 August 2005, Yeditepe University, Istanbul - Turkey. Pp. 597-599. 
Mollafilabi, A., H. Moodi, M.H. Rashed and Kafi, M. 2009. Effect of Plant Density and Nitrogen on Yield and Yield Components of Black Cumin (Nigella sativa L.). In: Proceedings of International Symposium on Medicinal and Aromatic Plants-SIPAM 2009 held at Djerba, Tunisia, March 26-28, 2009. Institut des Regions Arides, Tunisia. Pp. 115-126.

Moosazadeh, M., and Baradaran, R. 2011. Effect of Density and Time of Urea Foliar Application on Oil Yield and Essences Percentage of Black Cumin (Nigella sativa L.). Iranian Journal of Field Crops Research. 9(3): 422-427.

Sangwan, N.S., A.H.A. Farooqi, F. Shabih and Sangwan, R.S. 2001. Regulation of essential oil production in plants. Plant Growth Regulation. 34 (1): 3-21.

Shabestari, A.M., and Moradi, E. 2013. The effect of irrigation interval and plant density on the amount of active ingredient linoleic acid and oleic acid in the oil of black cumin (Nigella sativa). In: Proceedings of 2nd National Congress on Medicinal Plants, 15, -16 May 2013, Tehran- Iran. 294.

Shrivastava, R.M., R.C. Agrawal and Parveen, Z.J. 2011. A review on therapeutic applications of Nigella sativa. J Chem. Chem Sci. 1 (4): 241-248.

Talafih, K.A., N.I. Haddad, B.I. Hattar and
Kharallah, K. 2007. Effect of Some Agricultural Practices on the Productivity of Black Cumin (Nigella sativa L.) Grown under Rainfed Semi-Arid Conditions. Jordan Journal of Agricultural Sciences. 3 (4): 385-397.

Tuncturk, M., Z. Ekin and Turkozu, D. 2005. Response of black cumin (Nigella sativa L.) to different seed rates growth, yield components and essential oil content. Journal of Agronomy. 4 (3): 216-219.

Vaseghi, A., A. Ghanbari, M. Heydari,and Davazdahemami, S. 2013. Effect of sowing date and growing season on agronomical characters of Isfahanian and Indian black cumin. In: Proceedings of 2nd National Congress on Medicinal Plants, 15-16 May 2013, Tehran- Iran. 494.

Wallace, R.K., 2013. Modern research on Black Cumin. Doshaguru. Available at: http://www.doshaguru.com/ [Accessed on 17-07-2017].

Watson DJ (1958). The dependence of net assimilation rate on leaf-area index. Ann. Bot. 22: 37-54.

Wiersum, K.F., A.P. Dold, M. Husselman and Cocks, M. 2006. Cultivation of medicinal plants as a tool for biodiversity conservation and poverty alleviation in the Amatola region, South Africa. Frontis. 17: 43-57.

\section{How to cite this article:}

Giridhar, K., G. Sathyanarayana Reddy, S. Surya Kumari, A. Lalitha Kumari and Sivasankar, A. 2017. Influence of Sowing Window and Plant Density on Growth, Phenology, Yield and Quality of Nigella sativa L. in Coastal Humid Tropic. Int.J.Curr.Microbiol.App.Sci. 6(9): 499512. doi: https://doi.org/10.20546/ijcmas.2017.609.060 